\title{
KAJIAN POLA PENGOBATAN PENDERITA KANKER SERVIKS PADA PASIEN RAWAT INAP DI INSTALASI RSUD ABDUL WAHAB SJAHRANIE PERIODE 2014-2015
}

\author{
Yuniar Firsty Oktavia Lantika, Rolan Rusli, Welinda Dyah Ayu \\ Fakultas Farmasi Universitas Mulawarman, Samarinda, Kalimantan Timur \\ email: yunfirst93@gmail.com
}

\begin{abstract}
ABSTRAK
Kanker organ reproduksi termasuk jenis kanker yang banyak terjadi pada wanita, salah satunya yaitu kanker serviks yang disebabkan oleh infeksi Human Papilloma Virus (HPV) dan salah satu cara pengobatan kanker yang digunakan adalah pengobatan kemoterapi secara injeksi intravena melalui pembuluh darah. Tujuan dari penelitian ini adalah untuk mengetahui karakteristik pasien kanker serviks, pola pengobatan kemoterapi pasien kanker serviks, dan dosis kemoterapi yang digunakan pasien kanker serviks. Penelitian ini bersifat deskriptif dengan metode retrospektif. Pengumpulan data dilakukan dengan mencatat rekam medik pasien (responden) dengan jumlah total sebanyak 22 responden yang memiliki karakteristik yaitu berdasarkan usia terbanyak adalah usia 31-40 tahun sebesar 50\%, berdasarkan hubungan antara usia pertama kali menikah dengan jumlah pernikahan terbanyak adalah usia 15-20 tahun dan menikah sekali sebesar 64\%, dan berdasarkan metastase terbanyak adalah metastase IIIB sebesar $42 \%$. Adapun pola pengobatan kemoterapi berdasarkan pemilihan jenis dan golongan obat kemoterapi terbanyak adalah kombinasi obat kemoterapi karboplatin-paxus sebesar $86 \%$ dan berdasarkan efek samping obat kemoterapi terbanyak adalah efek samping obat mual muntah sebesar $50 \%$. Dosis pengobatan kemoterapi sesuai dengan hasil perhitungan dosis berdasarkan BSA (Body Surface Area) dan ClCr (Creatinine Clearance).
\end{abstract}

Kata kunci : $\quad$ Kanker Serviks, Karakteristik Pasien, Pola Pengobatan Kemoterapi Pasien, Dosis.

\begin{abstract}
Reproductive organ cancer included the type of cancer that is more common in women, one of which is cervical cancer that caused by infection of Human Papilloma Virus (HPV) and one of the ways used to cancer treatment is chemotherapy by injection intravenously through a vein. The aim of this study was to determine the characteristics of patients with cervical cancer, cervical cancer patients treatment patterns, and doses of cervical cancer patients. This is a descriptive study with retrospective method. Data was collected by recording the medical record data (respondent) with a total number of 22 respondents which has the characteristic that is based on the age of majority is the age of 31-40 years by 50\%, based on the relationship between age when first married with the highest number of weddings at the age of 15-20 years and married once by $64 \%$, and based on the most metastases is metastases IIIB by $42 \%$. The chemotherapy treatment patterns based on the selection of types and classes of chemotherapy drugs most used which a combination of chemotherapy drugs carboplatin-paxus by $86 \%$ and based on the most side effects of chemotherapy drugs is nausea and vomiting by 50\%. The dose of chemotherapy treatment in accordance with the calculated dose based on BSA (Body Surface Area) and ClCr (Creatinine Clearance).
\end{abstract}

Keywords: Cervical Cancer, Patient Characteristics, Patient Treatment Chemotherapy Patterns, Doses.

Submitted on: 8 November 2017 Accepted on: 1 December 2017

DOI: https://doi.org/10.25026/jsk.v1i8.89

\section{PENDAHULUAN}

Penyakit kanker merupakan penyakit ginekologik yang memiliki tingkat keganasan yang cukup tinggi. Di indonesia menjadi penyebab kematian utama lebih dari 250 ribu kematian pada tahun 2005, dimana kurang dari $80 \%$ dari kematian tersebut terjadi akibat kanker 
pada wanita. Pada Negara-negara berkembang diperkirakan akan terus meningkat $25 \%$ dalam kurun waktu 10 tahun mendatang jika tidak dilakukan tindakan pencegahan (Sandina, 2011).

Di seluruh dunia, lebih dari $90 \%$ kanker serviks disebabkan oleh infeksi Human Papilloma Virus (HPV). Kanker serviks merupakan keganasan yang terjadi pada leher rahim. Penyakit kanker serviks menunjukkan adanya sel-sel jaringan yang tumbuh terus menerus dan tidak terbatas pada bagian leher rahim. Human Papilloma Virus (HPV) adalah kelompok besar virus yang sekitar 40 jenis dapat menginfeksi daerah genital dan beberapa memiliki resiko tinggi untuk kanker serviks. Jika sakit seseorang menjadi kronis dapat menyebabkan perubahan pada sel-sel leher rahim dan perubahan-perubahan yang dapat menyebabkan kanker (Rasjidi, 2010).

Prinsip kerja pengobatan kanker serviks adalah dengan meracuni atau membunuh sel-sel kanker, mengontrol pertumbuhan sel kanker, dan menghentikan pertumbuhannya agar tidak menyebar, atau untuk mengurangi gejala-gejala yang disebabkan oleh kanker. Kemoterapi bersifat sistemik, berbeda dengan pembedahan dan radiasi yang bersifat setempat, karenanya kemoterapi dapat menjangkau sel-sel kanker yang mungkin sudah menjalar dan menyebar ke bagian tubuh yang lain. Dua atau lebih obat sering digunakan sebagai suatu kombinasi, agar menggunakan obat yang bekerja pada bagian yang berbeda dari proses metabolisme sel, sehingga akan meningkatkan kemungkinan dihancurkannya jumlah sel-sel kanker. Selain itu, efek samping yang berbahaya dari kemoterapi dapat dikurangi jika obat dengan efek beracun yang berbeda digabungkan, masing-masing dalam dosis yang lebih rendah dari pada dosis yang diperlukan jika obat itu digunakan tersendiri (Junaidi, 2007).

Pengobatan kanker serviks dan dosis yang diberikan pada pasien beragam sesuai dengan stadium kanker serviks dan berat badan, serta tinggi badan pasien yang dapat menimbulkan ketidaktepatan terapi yang diberikan kepada pasien kanker serviks. Sehingga peneliti tertarik untuk meneliti dan mengetahui pola pengobatan yang dilakukan dan kesesuaian dosis yang diberikan dibandingkan dengan berat badan dan tinggi badan pasien (Junaidi, 2007).

\section{METODE PENELITIAN}

Jenis penelitian yang digunakan adalah penelitian deskriptif dengan pendekatan retrospektif, dengan menganalisis catatan rekam medik pasien kanker serviks yang diterapi dengan pengobatan kemoterapi bulan januari periode 2014 sampai bulan juni periode 2015 di RSUD Abdul Wahab Sjahranie Samarinda, Kalimantan Timur.

\section{HASIL DAN PEMBAHASAN}

\section{a. Karakteristik responden}

Karakteristik pasien kanker serviks di RSUD Abdul Wahab Sjahranie periode 2014-2015 berdasarkan usia pasien ditabulasikan pada Tabel 1 .

Tabel 1. Distribusi Pasien Kanker Serviks Berdasarkan Usia

\begin{tabular}{ccc}
\hline Usia & Jumlah Pasien (orang) & Persentase $(\%)$ \\
\hline $31-40$ tahun & 11 & 50 \\
$41-50$ tahun & 7 & 32 \\
$51-60$ tahun & 3 & 14 \\
$>60$ tahun & 1 & 4 \\
\hline Total & 22 & 100 \\
\hline
\end{tabular}


Tabel 2. Distribusi Pasien Kanker Serviks Berdasarkan Hubungan antara Usia Pertama Kali menikah dengan Jumlah pernikahan pasien

\begin{tabular}{ccc}
\hline Hubungan usia dengan jumlah pernikahan & Jumlah Pasien (orang) & Persentase (\%) \\
\hline 15-20 tahun dan menikah sekali & 14 & 64 \\
21-30 tahun dan menikah dua kali & 4 & 18 \\
31-40 tahun dan menikah dua kali & 4 & 18 \\
\hline Total & 22 & 100 \\
\hline
\end{tabular}

Berdasarkan Tabel 1 diperoleh bahwa sebagian besar responden berada pada umur 31-40 tahun (50\%). Hal ini berkesesuaian dengan yang dilaporkan oleh Siboro (2006) bahwa insiden kanker serviks tertinggi pada usia 35-55 tahun. Pada usia 31-40 tahun merupakan masa yang memungkinkan seorang wanita terkena kanker serviks maka wanita usia $>35$ tahun diharapkan dapat melaksanakan pemeriksaan rutin terhadap kesehatannya terutama pemeriksaan rutin gejala kanker serviks sehingga jika penyakit ini ditemukan dengan cepat dan mudah ditanggulangi jika pada stadium awal jika dibandingkan ditemukan pada stadium lanjut.

Hasil penelitian juga menujukkan bahwa terdapat pasien usia 51-60 tahun (14\%) dan >60 tahun (4\%) dimana pada masa ini merupakan usia yang rentan terkena kanker serviks, karena semakin tua usia seseorang, maka semakin meningkat risiko terjadinya kanker serviks. Meningkatnya risiko kanker serviks pada usia lanjut merupakan gabungan dari meningkatnya dan bertambah lamanya waktu pemaparan terhadap karsinogen serta makin melemahnya sistem kekebalan tubuh akibat usia.

Karakteristik pasien kanker serviks di RSUD Abdul Wahab Sjahranie periode 2014-2015 berdasarkan hubungan antara usia pertama kali menikah dengan jumlah pernikahan pasien ditabulasikan pada Tabel 2.
Berdasarkan Tabel 2 terlihat bahwa usia pertama kali menikah terbanyak yaitu dihasilkan pada usia 1520 tahun dan menikah sekali sebesar 64 $\%$. Hal ini dapat disimpulkan bahwa pasien kanker serviks di RSUD A.W. Sjahranie periode tahun 2014-2015 yaitu menikah pada usia muda dan menikah sekali.

Pasien kanker serviks yang menikah satu kali sebenarnya tidak berpotensi terkena virus HPV karena pasien tidak melakukan hubungan seksual dengan pasangan yang berbeda sehingga memiliki risiko lebih kecil untuk terkena virus HPV yang mengakibatkan kanker serviks tersebut. Namun, pasien tersebut menikah pada usia 15-20 tahun. Hal ini karena pada usia $<20$ tahun tersebut organ seksual atau sel mukosa belum matang dan masih rentan terhadap rangsangan sehingga tidak siap untuk menerima rangsangan dari luar dari zat-zat kimia yang dibawa sperma, sehingga sel-sel mukosa bisa berubah sifat menjadi kanker (Wahidin, 2011).

Pasien kanker serviks yang menikah dua kali akan berpotensi terkena virus HPV karena pasien melakukan hubungan seksual dengan pasangan seks yang berbeda sehingga memiliki risiko lebih besar untuk terkena virus HPV yang mengakibatkan kanker serviks. Pada usia $>30$ tahun wanita sangat berpotensi terkena kanker serviks karena golongan wanita ini akan terus menerus mengalami ovulasi tanpa jeda sehingga rangsangan 
terhadap endometrium terjadi terus menerus sehingga dapat membuat sel-sel endometrium berubah sifat menjadi kanker (Syatriani, 2011).

Hubungan antara usia dengan jumlah pernikahan yaitu semakin banyak seseorang melakukan pernikahan, maka memiliki peluang besar terkena penyakit kanker serviks. Menurut teori peluang terjadi pada dua kali pernikahan, tetapi hasil penelitian yang diperoleh yaitu pada satu kali pernikahan pasien terkena kanker serviks. Hal ini dapat disebabkan oleh beberapa faktor lainnya, seperti faktor gaya hidup pasien, pola makan pasien, atau faktor kesehatan pasien.

Karakteristik pasien kanker serviks di RSUD Abdul Wahab Sjahranie periode 2014-2015 berdasarkan metastase pasien di tabulasikan pada Tabel 3.

Tabel 3. Distribusi Pasien Kanker Serviks Berdasarkan Metastase

\begin{tabular}{ccc}
\hline Metastase & Jumlah Pasien (orang) & Persentase $(\%)$ \\
\hline Metastase 1b2 & 1 & 4 \\
Metastase IIa & 1 & 4 \\
Metastase IIb & 7 & 32 \\
Metastase IIIa & 4 & 18 \\
Metastase IIIb & 9 & 42 \\
\hline Total & 22 & 100 \\
\hline
\end{tabular}

Tabel 3 diperoleh bahwa metastase terbanyak yang diderita pasien kanker serviks yaitu metastase IIb sebanyak 32\%, dimana penyebaran kanker telah menyebar ke jaringan sekitar vagina dan serviks, namun belum sampai ke dinding panggul yang menggunakan pengobatan kemoterapi dan metastase IIIb sebanyak $42 \%$, dimana penyebaran kanker menyebar ke parametrium sampai dinding panggul yang menggunakan pengobatan kemoterapi (NCCN, 2013).

Metastase $1 \mathrm{~b} 2$ pada penelitian ini sebanyak 1 responden (4\%), dimana penyebaran kanker dapat dilihat tanpa mikroskop dengan kedalaman $>4 \mathrm{~cm}$ yang menggunakan pengobatan kemoterapi. Metastase IIa sebanyak 1 responden (4\%), dimana penyebaran kanker meluas sampai ke atas vagina, tapi belum menyebar ke jaringan yang lebih dalam dari vagina yang menggunakan pengobatan kemoterapi. Metastase IIIa sebanyak 4 responden (18\%), dimana penyebaran kanker menyebar ke sepertiga vagina bawah yang menggunakan pengobatan kemoterapi (NCCN, 2013).

\section{b. Pola Pengobatan Kemoterapi Pasien Kanker Serviks}

Pengobatan kemoterapi pada kanker lebih sering digunakan suatu kombinasi dua atau lebih obat kemoterapi - Tujuan terapi kombinasi adalah untuk menggunakan obat yang bekerja pada bagian yang berbeda dari proses metabolisme sel, sehingga akan meningkatkan kemungkinan dihancurkannya jumlah sel-sel kanker. Adapun golongan obat yang digunakan pada pengobatan kemoterapi pasien kanker serviks adalah KarboplatinPaclitaxel, dan Cisplatin-VincristineBleomysin, serta Karboplatin-Paclitaxel dan Cisplatin-Vincristine-Bleomysin, yang ditabulasikan pada Tabel 4.

Pola pengobatan kemoterapi pasien kanker serviks di RSUD Abdul Wahab Sjahranie periode 2014-2015 berdasarkan golongan obat dan jenis obat 
yang digunakan pasien di tabulasikan pada Tabel 4.

Berdasarkan Tabel 4 diperoleh bahwa hasil golongan obat dan jenis obat yang diberikan pasien kanker serviks menggunakan pengobatan kombinasi. Kombinasi obat tertinggi dihasilkan pada kombinasi obat karboplatin-paclitaxel sebanyak 19 responden $(86 \%)$, dimana kombinasi ini digunakan untuk menurunkan kadar kreatinin pasien kanker serviks yang lebih dari batas kadar normal kreatinin $(0,5-1 \mathrm{mg} / \mathrm{dl})$ atau mengalami kerusakan ginjal parah , sedangkan hasil kombinasi terendah yaitu kombinasi cisplatin-vincristin-bleomysin sebanyak 1 responden (5\%), dimana kombinasi ini digunakan untuk menaikkan kadar kreatinin pasien kanker serviks yang kurang dari batas kadar normal kreatinin $(0,5-1 \mathrm{mg} / \mathrm{dl})$ atau mengalami kerusakan ginjal ringan (Guidline, 2013). dan kombinasi antara keduanya yaitu karboplatin-paclitaxel dengan cisplatin-vincristin-bleomysin sebanyak 2 responden (9\%), dimana pada tahun 2014 diberikan kombinasi cisplatin-vincristin-bleomysin yang digunakan pada pasien untuk menaikkan kadar kreatinin pasien kanker serviks yang kurang dari batas kadar normal kreatinin $(0,5-1 \mathrm{mg} / \mathrm{dl})$ atau mengalami kerusakan ginjal ringan, namun pada tahun 2015 diberikan kombinasi karboplatin-paclitaxel yang digunakan pada pasien untuk menurunkan kadar kreatinin pasien kanker serviks yang lebih dari batas kadar normal kreatinin $(0,5-1 \mathrm{mg} / \mathrm{dl})$ atau mengalami kerusakan ginjal parah, sehingga pasien dapat disimpulkan bahwa tiap tahun keadaan pasien mengalami kerusakan ginjal yang parah (NCCN, 2013).

Kombinasi karboplatin-paxus ini digunakan karena carboplatin bekerja pada fase sintesis DNA (fase $S$ ) dan paxus bekerja pada fase pembelahan sel (fase $\mathrm{M}$ ), dimana siklus sel otomatis akan terganggu dan akan menginduksi suatu apoptosis (kematian sel). Sehingga kombinasi karboplatin dan paxus ini akan saling menguatkan dan meningkatkan efektifitas kemoterapi terhadap kanker yang memiliki sifat toksik yang lebih ringan (Perbowo, 2008).

Kombinasi cisplatin-vincristinbleomysin ini digunakan karena cisplatin bekerja pada fase replikasi DNA (fase G1 dan fase G2), vincristin bekerja pada fase sinteseis DNA dan fase pembelahan sel (fase S, fase M), bleomysin bekerja pada fase replikasi DNA dan fase pembelahan sel (fase G2, fase M), dimana siklus sel otomatis akan terganggu dan akan menginduksi suatu apoptosis (kematian sel). Sehingga kombinasi cisplatinvincristin-bleomysin ini akan saling menguatkan dan meningkatkan efektifitas kemoterapi terhadap kanker yang memiliki sifat toksik yang lebih ringan (Lucida, 2011).

Pola pengobatan kemoterapi pasien kanker serviks di RSUD Abdul Wahab Sjahranie periode 2014-2015 berdasarkan efek samping obat yang digunakan pasien di tabulasikan pada Tabel 5.

Tabel 4. Golongan Obat dan Jenis Obat Kemoterapi yang Diberikan Pasien Kanker Serviks

\begin{tabular}{ccc}
\hline Kombinasi & Jumlah Pasien (orang) & Persentase (\%) \\
\hline Karboplatin-Paclitaxel & 19 & 86 \\
Cisplatin-Vincristine-Bleomysin & 1 & 5 \\
Karboplatin-Paclitaxel dan & 2 & 9 \\
Cisplatin-Vincristine-Bleomysin & & \\
\hline Total & 22 & 100 \\
\hline
\end{tabular}


Tabel 5. Efek Samping Obat Kemoterapi Pasien Kanker Serviks

\begin{tabular}{ccc}
\hline Efek Samping Obat & Jumlah Pasien (orang) & Persentase $(\%)$ \\
\hline Mual muntah & 11 & 50 \\
Mual Muntah+Nyeri & 3 & 13 \\
Mual Muntah+Anemia & 2 & 9 \\
Mual Muntah+ Pendarahan & 1 & 5 \\
Mual Muntah+Nyeri+Anemia & 3 & 13 \\
Mual Muntah+Nyeri+Pendarahan & 1 & 5 \\
Mual & 1 & 5 \\
Muntah+Anemia+Pendarahan & & \\
\hline Total & 22 & 100 \\
\hline
\end{tabular}

Tabel 6. Dosis Obat Kemoterapi Secara Intravena Pasien Kanker Serviks

\begin{tabular}{ccc}
\hline Kombinasi Obat Kemoterapi & Dosis & Kesimpulan \\
\hline Carboplatin-paclitaxel & Carboplatin (300 mg)-paclitaxel (175 mg) & Dosis sesuai \\
Cisplatin-vincristin-bleomysin & Cisplatin (50 mg)-vincristin (2 mg)-bleomysin (30 mg) & Dosis sesuai \\
\hline
\end{tabular}

Berdasarkan Tabel 5 diperoleh bahwa hasil efek samping obat pasien kanker serviks tertinggi adalah pada mual muntah yaitu $50 \%$ dan efek samping obat terendah adalah mual muntah+nyeri yaitu $13 \%$, mual muntah+anemia yaitu $9 \%$, mual muntah+pendarahan yaitu $5 \%$, mual muntah+nyeri+anemia yaitu $13 \%$, mual muntah+nyeri+pendarahan yaitu $5 \%$, dan mual muntah+anemia+pendarahan yaitu $5 \%$. Hal ini dapat disimpulkan bahwa efek samping obat yang terjadi pada pasien kanker serviks yaitu mayoritas mual muntah. Karena mual muntah memiliki tingkat emetogenisitas kemoterapi intravena berdasarkan pengobatan kemoterapi yang digunakan dalam penelitian ini yaitu dari golongan derivate platinum obat cisplatin merupakan risiko emesis tinggi (frekuensi muntah >90\%), obat carboplatin merupakan risiko emesis sedang (frekuensi muntah 30\%-90\%). Sedangkan golongan taxane yaitu paclitaxel (paxus) merupakan risiko emesis rendah (frekuensi muntah 10\%$30 \%$ ), bleomysin dan vincristine merupakan risiko emesis minimal (frekuensi <10\%). Mekanisme terjadinya mual muntah disebabkan karena pengobatan kemoterapi kanker serviks bersifat membunuh sel kanker, sel normal, ataupun sel yang baru tumbuh (berkembang). Pada lambung terdapat sel mukosa yang berfungsi untuk melindungi lambung. Namun, pengobatan kemoterapi kanker serviks telah membunuh sel mukosa tersebut, sehingga mukosa tidak terbentuk dan pelindung lambung pun hilang. Hal ini dapat mengakibatkan gangguan gastrointestinal (GI) seperti gejala maag dan mengalami luka pada lambung yang memicu terjadinya mual dan muntah (Solimando, 2004).

Pengobatan premedikasi pada nyeri yang diberikan dalam penelitian ini yaitu asam mefenamat, parasetamol dan tramadol. Dimana asam mefenamat (durasi aksi 2-6 jam) dan parasetamol (durasi aksi 2-4 jam) merupakan pengobatan nyeri atau analgetik ringan, sedangkan tramadol (durasi aksi 6 jam) merupakan pengobatan nyeri atau analgetik sedang. Pengobatan premedikasi pada pendarahan yang diberikan dalam penelitian ini yaitu asam 
tranexamat (kalnex) (durasi aksi 2-6 jam) merupakan pengobatan analgetik ringan. Pengobatan premedikasi pada mual muntah terbanyak yaitu pengobatan untuk mual muntah tertunda yang menggambarkan keterlambatan mual muntah akibat penggunaan terapi sitostatika yang terjadi setelah lebih dari 24 jam pemberian obat kemoterapi, mual muntah tertunda terjadi karena pemberian regimen kemoterapi cisplatin dan carboplatin (Rahmawati, 2009). Pengobatan premedikasi pada anemia yang diberikan yaitu SF (sulfate Ferous) sesuai dengan teori (Kar, 2005).

\section{c. Dosis Kemoterapi Secara Intravena yang Digunakan Pasien Kanker Serviks}

Dosis merupakan jumlah obat yang diberikan kepada penderita dalam satuan berat atau satuan isi atau unit-unit lainnya, dan dapat dinyatakan dalam satuan berat (g, mg, ug) atau satuan isi (liter, $\mathrm{ml}$ ).

Dosis obat kemoterapi secara intravena pasien kanker serviks di RSUD Abdul Wahab Sjahranie periode 20142015 di tabulasikan pada Tabel 6 .

Berdasarkan Tabel 6 diperoleh bahwa hasil dosis pengobatan kemoterapi sesuai dengan hasil perhitungan dosis berdasarkan BSA (Body Surface Area) dengan rumus perhitungan $\mathrm{BSA}=$ $\frac{\sqrt{B B(\mathrm{~kg}) \times T B(\mathrm{~cm})}}{3600}$ dan $\mathrm{ClCr}$ (Creatinine Clearance) dengan rumus perhitungan $\mathrm{ClCr}=\frac{(140-u m u r) \times B B}{72 \times S c r} \times 0,85$. Perhitungan BSA (Body Surface Area) digunakan untuk mengetahui ketepatan dosis pengobatan kemoterapi pada kombinasi pengobatan karboplatin-paxus yang mengalami kerusakan ginjal parah karena kadar kreatinin lebih tinggi dari kadar normal kreatinin $(0,5-1 \mathrm{mg} / \mathrm{dl})$ dan perhitungan klirens kreatinin $(\mathrm{ClCr})$ digunakan untuk mengetahui ketepatan dosis pengobatan kemoterapi pada kombinasi pengobatan cisplatinvincristin-bleomysin yang mengalami kerusakan ginjal ringan karena kadar kreatinin lebih rendah dari kadar normal kreatinin $(0.5-1 \mathrm{mg} / \mathrm{dl})(\mathrm{NCCN}, 2013)$.

Pengobatan

kemoterapi

digunakan secara intravena, karena intravena diberikan secara sistemik yang langsung berada di site targetnya melalui pembuluh darah vena pada vena-vena anggota gerak untuk mempercepat efek terapi yang ditimbulkan sehingga dapat meminimalisir tingkat keparahan kanker serviks pada pasien. Namun, terdapat efek yang ditimbulkan pada pemberian dengan rute intravena seperti terjadinya iritasi, obat yang telah disuntikkan tidak dapat diambil kembali karena konsentrasi yang diberikan terlalu tinggi, dan biaya yang relatif lebih mahal dibandingkan pemberian obat dengan rute oral sehingga kecepatan infus dan konsentrasi harus selalu dikontrol pada rute intravena (Perbowo, 2008).

Pemakaian pengobatan kemoterapi yang digunakan yaitu kombinasi karboplatin-paclitaxel, dimana penggunaannya yaitu terlebih dahulu menggunakan paclitaxel 175 $\mathrm{mg} /{ }^{\mathrm{m} 2}$ secara intravena selama $6 \mathrm{jam}$ yang diikuti dengan carboplatin 300 $\mathrm{mg} / \mathrm{m}^{2}$ secara intravena selama $12 \mathrm{jam}$ setiap hari (Perbowo, 2008). Sedangkan kombinasi cisplatin-vincristinbleomycin, dimana penggunaanya yaitu terlebih dahulu menggunakan bleomysin $30 \mathrm{mg} / \mathrm{m}^{2}$ secara intravena selama 24 jam dihari pertama, dihari kedua menggunakan vincristin $2 \mathrm{mg} / \mathrm{m}^{2}$ secara intravena selama 30 menit yang diikuti dengan cisplatin $50 \quad \mathrm{mg} / \mathrm{m}^{2}$ secara intravena selama 4 jam setiap hari (Lucida, 2011). 


\section{KESIMPULAN}

Berdasarkan hasil penelitian kanker serviks di instalasi rawat inap RSUD Abdul Wahab Sjahranie periode 2014-2015 dapat disimpulkan sebagai berikut:

1. Karakteristik berdasarkan usia terbanyak adalah usia 31-40 tahun sebesar $50 \%$, berdasarkan hubungan antara usia pertama kali menikah dengan jumlah pernikahan terbanyak adalah usia 15-20 tahun dan menikah sekali sebesar $64 \%$, dan berdasarkan metastase terbanyak adalah metastase IIIB sebesar $42 \%$.

2. Pola pengobatan kemoterapi berdasarkan pemilihan jenis dan golongan obat kemoterapi terbanyak adalah kombinasi obat kemoterapi karboplatin-paxus sebesar $86 \%$ dan berdasarkan efek samping obat kemoterapi terbanyak adalah efek samping obat mual muntah sebesar $50 \%$.

3. Dosis pengobatan kemoterapi sesuai dengan hasil perhitungan dosis berdasarkan BSA (Body Surface Area) dan $\mathrm{ClCr}$ (Creatinine Clearance).

\section{DAFTAR PUSTAKA}

[1] Aziz,F.M. 2002. Skrining dan Deteksi Dini Kanker Serviks. Balai Penerbit FKUI: Jakarta

[2] Guidline, NCCN. 2013. Ovarian Cancer Including Fallopian Tube Cancer and Primary Peritoneal Cancer. Guidline in Oncology: English
[3] Julian, Desmond \& Claire Marley. 1991. Coronary Heart Disease the Facts. Oxford University Press: New York

[4] Junaidi, Iskandar.2007. Kanker. PT. Bhuana Ilmu Popule: Jakarta

[5] Kar, Azmi Sariedj. 2005. Pengaruh Anemia dan Kanker terhadap Kualitas Hidup dan Hasil Pengobatan.Jurnal Sains Universitas Sumatra Utara: Medan

[6] Lucida, Henny. 2011. Analisis Aspek Farmakokinetika Klinik Pasien Gagal Ginjal pada IRNA Penyakit Dalam RSUD Dr.Djamil Padang. Jurnal Sains Teknologi Farmasi Volume 16 Nomer 2 Fakultas Farmasi Universitas Andalas: Padang

[7] Perbowo, Primandono. 2008. Perbandingan Kejadian Neurotropeni dan Neuropati Perifer Akibat Kemoterapi Adjuvan Paclitaxel-Carboplatin Antara Paclitaxel 3 jam dengan Paclitaxel Infus 24 jam pada Penderita Kanker Ovarium Stadium I-IV. Departemen Obstetric dan Ginekologi Fakultas Kedokteran UNAIR: Surabaya

[8] Rasjidi, Imam, Dr. 2010. Kanker Pada Wanita. PT.Gramedia: Jakarta

[9] Sandina, Dewi. 2011.9 Penyakit Mematikan Mengenali Tanda dan Pengobatannya. Smart pustaka: Yogyakarta

[10] Siboro, R. 2006. Karakteristik Penderita Kanker Serviks yang Dirawat Inap di RSUD H. Adam Malik Medan Tahun 2001-2005. Skripsi FKM-USU: Medan

[11] Solimando, Dominic A. 2004. Drug Information Handbook for Oncology $4^{\text {th }}$ Edition. Lexi Comp APHA: Amerika

[12] Syatriani, Sri. 2011. Faktor Risiko Kanker Serviks di Rumah Sakit Umum Pemerintah Dr. Wahidin Sudirohusodo Makassar, Sulawesi Selatan. Jurnal Kesehatan Masyarakat Nasional Volume 5 Nomer 6: Makassar

[13] Tapan, E. 2005. Kanker, Antioksidan dan Terapi Komplementer. PT.Elex Media Komputindo: Jakarta 